\title{
Бакинская военная операция в январе 1990 года как попытка подавления советским руководством азербайджанского национального движения по защите территориальной целостности республики
}

$\Pi$ родумывая в 1985 году перспективу перемен в СССР, архитекторы реформ и не подозревали, какое большое значение в истории перестройки займет национальный вопрос. Политика М.Горбачева во многих отношениях придала импульс этнонациональным процессам, направление которых было запрограммировано более ранними противоречиями. Эти противоречия имели исторические корни и проистекали как из этнических, так и из иных, социальных и политических факторов. В этнонациональных конфликтах периода перестройки действовали две основные силы: во первых, эмоциональная массовая народная стихия, ведомая радикальными маргинальными элементами и национальной интеллигенцией; вторая- республиканская номенклатура, оказавшаяся под давлением массовых выступлений, но готовая при случае использовать её в своих интересах. Беспрецедентной ситуация стала потому, что конфликты, однажды возникнув, продолжали развиваться. Затяжной характер конфликтов постепенно радикализировал массы.

Образование в 1923 году в составе Азербайджанской ССР территориальной автономии для армянского населения Нагорного Карабаха (Нагорно-Карабахская автономная область), при существовании отдельной Армянской республики Армянской ССР, неизменно сохраняло угрозу сепаратизма и конфликтный потенциал в отношениях между двумя народами. Существование двух этнически идентичных армянских национальных образований в рамках одного государства, т.е. Советского Союза, да ещё по соседству, было аналогично мине замедленного действия, которая обязательно должна была взорваться.

До 1980-х годов, не считая отдельных единичных случаев роста всплеска напряженности, в основном инициированных из Армении и выраженных в сборе подписей и обращений армянской интеллигенции в адрес союзного руководства, а также столкновений на бытовом уровне, имевших место между армянами и азербайджанцами в Нагорном Карабахе, советским властям удавалось, держа руку на пульсе, не давать выход информации об этих фактах за пределы границ автономии, а также на страницы союзной печати. В межнациональных отношениях Кремль действовал жестко, методом устрашения, тем самым контролируя мир, добрососедство между армянами, грузинами, азербайджанцами и многими другими народами и этносами на протяжении десятилетий. Это обеспечивалось не только неотвратимостью наказания того, кто преступил законы сосуществования в едином советском доме. За 
Союзом признавалась роль объективного третейского судьи. И он эту роль худо-бедно выполнял достаточно объективно. Однако горбачевская перестройка лишила Союз его эффективного оружия -опоры на силу, заменив ее ссылками на несуществующую демократию. А роль объективного третейского судьи Михаил Сергеевич подменил политикой равноудаленности. В результате, получилось, что нарушитель мира и закона виноват в той же мере, что и тот, чей покой нарушен дерзкими, необоснованными претензиями на исторические земли. Эта логика и подвела к уравнению в правах и агрессора, и его жертвы.

В ходе последней фазы конфликта, начавшейся во второй половине 80 -х годов XX века, армяно-азербайджанский территориальный конфликт впервые вырвался на страницы союзной и республиканской прессы, выйдя тем самым из латентного состояния и став объектом широкого обсуждения. Впервые, начиная с 1920-х годов, не в закрытых кабинетах или в ходе застолий, а открыто на официальном уровне было выдвинуто требование изменить административно-территориальное устройство советского государства, являвшееся одной из главных истин, на которых держался "нерушимый союз". Одновременно, впервые руководство Армении, наряду с политической поддержкой сепаратистского движения в Нагорном Карабахе, предприняло конкретные юридические шаги по воссоединению НКАО с Арменией. Требование о передаче НКАО Армении идеологически базировалось, во первых, на мифической армянской исконности Карабаха, и , во -вторых, на праве нации на самоопределение, однобоко раздутом и вырванном из системы конституционных принципов советского государства, включавших также уважение территориальной целостности республик. Вся пропагандистская риторика сепаратистского движения старательно встраивалось в контексты идеологических процессов перестройки. А именно, критическое переосмысление истории СССР использовалось для распространения надуманных утверждений о том, что якобы Сталин в 1921 году «отдал» Карабах Азербайджану. Идеи демонтажа командно-административной системы в СССР, активно обсуждавшиеся в обществе переносились на национальногосударственное устройство Советского Союза и использовались для обоснования пересмотра территориально-правового статуса НКАО. Критика социальноэкономических проблем советского общества, в свою очередь, служила благоприятным фоном для раздувания настоящей истерии вокруг социально-экономических и национально-культурных проблем автономной области, которая на самом деле находилась в относительно лучшем состоянии по сравнению с другими горными районами Азербайджанской ССР. Пропагандистская деятельность армян подкреплялась активной политической и организаторской работой. Под руководством эмиссаров из Армении создавались организационные основы сепаратистского движения, легализовавшиеся позднее в НКАО под названиями «Крунк» и «Карабах».

Новый этап конфликта в Нагорном Карабахе стал разгораться практически с момента прихода к власти в руководстве СССР М.Горбачева. Более того, в кремлевских верхах были хорошо информированы о настроениях в Армении и Нагорном Карабахе, хорошо знали, что там происходит и что готовится, ибо там особо не скрывали своих намерений и планов, тщательно встраивая в демократическую риторику перестройки радикально-сепаратистские требования. Об этом свидетельствуют мысли, высказанные 
М.Горбачевым в своих мемуарах. Горбачев отмечал: "За три года (имеется в виду период 1985-1987 годов - И.Н.) ЦК получил 500 писем о ситуации в Нагорном Карабахе. Перестройка привела в движение большие внутренние силы, начали вскрываться застарелые нарывы. Возрождаются национальные чувства, а вместе с ними и национальный экстремизм" ${ }^{197}$.

Таким образом, Горбачев вынужден был признать, что задолго до начала кровавого этапа конфликта в 1988 году Москва была в курсе сложных процессов, которые происходили вокруг Нагорного Карабаха, связанных с ростом среди местных армян национального экстремизма. Москва получала об этом информацию, прежде всего, по каналам спецслужб. Ф.Д.Бобков, занимавший в те годы должность первого заместителя председателя КГБ так писал о назревавшем конфликте: « Уже два года мы били тревогу о грядущем конфликте между Арменией и Азербайджаном...В Армению была послана бригада, которая подтвердила: в Закавказье зреют межнациональные конфликты и надо принимать срочные меры. Вопрос был поставлен на обсуждение в секретариате ЦК КПСС. Однако все выводы и предложения бригады из решений убрали и сгладили остроту вопроса. Никто не хотел открыто признавать наличие конфликтов на национальной почве, что в некоторых республиках назревают социальные потрясения ...ЦК КПСС пресекал любые попытки раскрыть истину» 198

Партийное руководство Азербайджанской ССР также была в курсе событий, происходивших вокруг Нагорного Карабаха, и ещё задолго до начала последней кровавой фазы конфликта систематически ставило об этом в известность Москву. Об этом пишет в своей книге бывший председатель Комитета Государственной безопасности Азербайджанской ССР Вагиф Гусейнов со ссылкой на слова бывшего председателя областного отделения КГБ НКАО полковника Г.Септа: «О фактах активизации националистических проявлений регулярно докладывалось руководству, сообщалось по инстанциям. Фиксировались и случаи приезда эмиссаров из Еревана, оживление группировок, находившихся в поле зрения службы. Докладывалось, писалось начальству, неоднократно обсуждались возникающие проблемы с Кеворковым (секретарь Областного комитета партии НКАО-И.Н.). Москвичи смотрели на все это сквозь пальцы, мол, у нас тут и не такое разворачивается. Бакинское руководство ни разу не проявило должного беспокойства: ни в случае с целенаправленным распространением книги «Очаг» З.Балаяна, фактически ставшей призывом к «миацуму» (присоединение области к Армении), ни позже, когда сепаратисты ловко прикрылись лозунгами большей демократии, гласности. К февралю все было ясно. Не было бы Сумгаита, полыхнуло бы где-нибудь в другом месте». Г. Септа, как и многие другие обладатели информации о невидимых для внешнего взгляда процессах, не говорит о широком заговоре. Но он ставит вопрос о том, что сведения о подлинных настроениях и устремлениях в Армении и НКАО не могли не стекаться в единый Центр - Москву. Ни он, ни другие не чувствовали обеспокоенности московского начальства. Инертно вели себя партийные органы в Баку ${ }^{199}$.

\footnotetext{
${ }^{197}$ Горбачев М.С. Жизнь и реформы. Книга 1, Москва, 1995, с.506

${ }^{198}$ Бобков Ф. КГБ и власть. Москва, 2009, с. 298-299.

${ }^{199}$ Гусейнов В. Больше, чем одна жизнь. Книга 2. Москва, 2013, с.118-119
} 
После трагических событий в Сумгаите 27-28 февраля 1988 года, спровоцированных советскими спецслужбами в тандеме с армянскими националистами, в ходе которых погибло 32 человека (26 армян и 6 азербайджанцев), конфликт перешел в кровавую плоскость. Развернулась антиазербайджанская пропагандистская компания в прессе уже во всесоюзном и международном масштабе с использованием умело смоделированного образа азербайджанской нации. Азербайджан же благодаря этим усилиям стал восприниматься не иначе как агрессивная, реакционная, непримиримая сторона межнационального конфликта.

В Кремле считали, что очередная армянская возня вокруг идеи передачи Нагорного Карабаха Армении будет заглушена традиционным методами профилактического воздействия местных партийных и правоохранительных органов и, наконец, сменой руководителей республик. Однако новому партийному руководителю Азербайджана в лице А.Везирова, назначенному на этот пост в мае 1988 года, не хватило тактической гибкости, мудрости при решении Карабахской проблемы и проблемы беженцев из Армении. Он не сумел политически консолидировать азербайджанское общество на почве солидарности народа и власти. В результате обострения конфликта начался исход азербайджанцев из Нагорного Карабаха и Армении, а армян из Азербайджана. Таким образом, в воронку конфликта оказалась вовлечена еще большая масса людей, значительно расширилась география пространства конфликта с перспективой превращения в непосредственную зону столкновений Баку и всех тех населенных пунктов Азербайджана, где проживали армяне и где стихийно оседали беженцы из Армении.

Начиная с мая 1988 года в Баку начались митинги, которые деморализовали жизнь в республике, привели к простою работы многих предприятий, учебных заведений. На митингах, которые охватили столицу республики выдвигались в основном требования о защите суверенитета и территориальной целостности республики. Таким образом, на начальном этапе национально-демократическое движение в Азербайджане начиналось на Карабахской волне.

Начиная с 17 ноября 1988 года митинг на главной площади столицы (в то время носил им.В.Ленина, а позже «Свободы») стал бессрочным. Волнения среди населения подхлестывались очередной волной беженцев, продолжавших прибывать из Армении. Люди вновь и вновь требовали твердых гарантий безопасности для азербайджанского населения Армении, восстановления правопорядка в НКАО и обеспечения территориальной целостности республики. В этих условиях властям пришлось идти на крайнюю меру - было решено вводить особое положение, установить в столице и некоторых других местах комендантский час. Это был серьезный политический шаг, означавший признание кризиса власти, оказавшейся и в самом деле неспособной вести публичный диалог с народом, контролировать сложную социально-политическую ситуацию в республике.

Двусмысленная позиция Кремля все больше провоцировал ожесточенную полемику между конфликтующими сторонами, вызывая рост недоверия к центральным властям с обеих сторон. В итоге автономная область полностью вышла из-под контроля не только Баку, но и Москвы. К концу 1989 г. стало очевидным, что линия, 
проводившаяся ЦК КПСС в карабахском вопросе, не только не дала положительных результатов, но и обернулась серьезными политическими просчетами и потерями.

В конце декабря 1989 года с советско-иранской границы в Баку стали поступать сообщения, одно тревожнее другого. Случилось то, во что никак не могли (а может, не хотели) поверить ни в Баку, ни в Москве, - государственная граница СССР была разрушена на десятках километров, многие тысячи людей по обе стороны Араза встретились, не веря собственным глазам, что такое возможно. Однако разбор железобетонной стены между Восточным и Западным Берлином Москва называла новым мышлением, а разбор в Нахичевани и Джалилабаде колючей проволоки, проходящей на расстоянии 0,5 км от границы, стала называть устремлением экстремистов. Именно после этих событий в Москве поняли, что в одной из союзных республик возникла угроза выхода из состава СССР, и события перешли в драматическую стадию. На заседании Политбюро ЦК КПСС 2 января 1990 года председатель КГБ СССР В.Крючков, касаясь событий в Азербайджане, отмечал: «Развитие ситуации приобрело непредсказуемый характер. В Джалилабаде власть перешла к так называемому Народному фронту. Происходит фактическое разрушение государственной границы. Необходима помощь пограничникам со стороны армии. Образована Комиссия по межнациональным отношениям». На следующий день, 3 января на совещании в Ново-Огареве, касаясь ситуации сложившейся в стране, Горбачев обещал : "Считаю своей главной задачей провести страну через перестройку без гражданской войны. Жертвы неизбежны. Там и здесь кого-то убивают, но это стихийно, от этого никуда не денешься. Другое дело - подавлять силой, оружием. Этого от меня не дождутся" ${ }^{200}$.

В связи со сложившейся обстановкой, некоторые члены ЦК КП Азербайджана выступили с резкой критикой политики Кремля. В своём выступлении на партийнохозяйственном активе 8 января 1990 года секретарь ЦК КП Азербайджана Гасан Гасанов (ныне посол Азербайджанской Республики в Польше -И.Н.) отмечал: «При всей значимости всех прочих проблем мы не сможем вывести республику из сложившегося состояния, не разобравшись в первую очередь в уроках и ошибках Карабахского кризиса, не определив методы его решения. Проводимые под знаменем территориальной целостности забастовки на предприятиях Монголии мы называем справедливым делом. Аналогичные забастовки на предприятиях Азербайджана действиями антиперестроечных сил. Мы недоумеваем, почему страна не знает, что карабахский конфликт возник в силу исторических территориальных амбиций Армении, что первыми погибшими жертвами были азербайджанцы, что первыми беженцами стали азербайджанцы...160 тысяч азербайджанцев в сопровождении убийц, насилия и разбоя, морально униженные и нравственно ущемленные, полностью изгоняются из Армении. Самолетами, вертолетами, вагонами, рефрижераторами, невзирая на наличие там военной комендатуры, в НКАО завозится оружие. Оно активно используется. Происходят вооруженные агрессии». В заключении своего выступления Г.Гасанов призвал руководство страны вернуться в конституционное

\footnotetext{
${ }^{200}$ В Политбюро ЦК КПСС. По записям Анатолия Черняева, Вадима Медведева, Георгия Шахназарова
} (1985-1991). Сост. А. Черняев (рук. проекта), А. Вебер, В. Медведев. Москва, 2008,c.571 
поле, а именно «направить всю силу советской Конституции, силы наших законов, силу Устава КПСС на немедленное, неукоснительное устранение территориальных притязаний Армении к Советскому Азербайджану» ${ }^{201}$.

Однако, поступавшие из Нагорного Карабаха информация уже напоминала военные сводки. Начались нападения со стороны Армении на азербайджанские села в Нахичевани. Армянскими террористами были опустошены 10 азербайджанских сел в Губатлинским районе. Под постоянным обстрелом находился Лачинский район. В Степанакерте (Ханкенди) состоялось нападение на автобус с азербайджанскими пассажирами. Были зафиксированы обстрелы азербайджанских сел из пусковых установок Алазань. Это вынудило Москву ввести 15 января 1990 года в НКАО чрезвычайное положение. Однако эти акты ещё более обострили ситуацию в столице республики, где в это время шли митинги с открытыми требованиями об отставке партийного руководства республики. В отдельных районах Баку были зафиксированы случаи нападения на армянские квартиры. То есть повторялся сценарий сумгаитской провокации 1988 года.

Уже начиная с января 1990 года в Баку, постепенно из Москвы стали направляться эмиссары различных рангов, которые фактически взяли в свои руки управление республикой. В своих выступлениях по республиканскому телевидению и на митингах они убеждали народ, что в городе не будет введено чрезвычайное положение, не войдут войска, и все требования митингующих будут выполнены. Однако уже 19 января 1990 году в Баку прибыли министр обороны Д.Язов, министр внутренних дел В.Бакатин, уже здесь находились заместитель председателя КГБ СССР Г.Агеев, командующий внутренними войсками СССР Ю. Шаталин, командующий воздушно-десантными войсками генерал В.Ачалов. То есть все шло к проведению карательной операции, которое тщательно скрывали от населения, а за несколько часов до ввода войск сотрудники группы «Альфа» вообще организовали взрыв энергоблока республиканского телевидения, которое привело к прекращению телевидения. Описывая последние часы перед трагедией и то, как принималось решение о введение чрезвычайного положения в Баку, пресс-секретарь Михаила Горбачева Андрей Грачев в своих воспоминаниях писал: «Горбачёв покорился традиционной участи правителя империи - в Баку на усмирение беспорядков были откомандированы Д.Язов и В.Бакатин. Напутствуя их, В.Крючков и даже А.Яковлев говорили о необходимости преодолеть «синдром Тбилиси» и проявить «твердость». Министры потребовали не только устного поручения главы государства, но и юридического мандата: указа о введении чрезвычайного положения. Горбачёв попробовал было, как в случае с Карабахом, укрыться за фразой «будете действовать по обстановке», но, когда оба министра отказались без указа вводить войска, он решился: «Летите, указ придет следом». И, сняв телефонную трубку, сказал Лукьянову: «Анатолий, давай текст» ${ }^{202}$.

19 января 1990 г. Михаил Горбачёв без ведома Верховного Совета Азербайджанской ССР подписал указ «О введении чрезвычайного положения в Баку» с 00:00 часов 20

\footnotetext{
201 Балаев А., Мирза Р. События 20 января. Документы, позиции, комментарии (1990-2000). Баку, 2000, c. $45-55$

${ }^{202}$ Грачев А. "Горбачёв. Человек, который хотел, как лучше...». Москва, 2001,с.136
} 
января. Из-за взрыва энергоблока на республиканском телевидении ни по телевидению, ни по радио не удалось довести до сведения населения указ о введении чрезвычайного положения. Таким образом, воинские подразделения без предупреждения в ночь с 19 на 20 января перешли в наступление на Баку.

Генерал Александр Лебедь, который принимал участие в Бакинской военной операции в качестве командира воздушно-десантной дивизии, позже вспоминал: «Самолёт, в котором я летел, приземлился в густых сумерках на аэродроме Кала, в 30 километрах от Баку... Задача — взять двухмиллионный город - милая и простенькая. В соответствии с установкой и взяли город Баку - пропахали и проутюжили танками все, что встречалось на пути, вместе с людьми, естественно. А это всё-таки не сапёрные лопатки, сравнительно недавно применённые десантниками в Тбилиси» ${ }^{203}$.

В заключении комиссии Верховного Совета Азербайджанской Республики, созданной 21 января 1990 года и расследовавшей эту трагедию, указывалось, что в результате операции по захвату города погибли 131 человек, из них - 117 азербайджанцев, 6 русских, 3 евреев, 3 татар. Среди них - 124 мужчин, 7 женщин и 7 несовершеннолетних детей. В ту ночь погибли два сотрудника скорой помощи при исполнении своих служебных обязанностей. Кроме этого, в ходе военной операции было ранено 744 человека, 4 человека пропали без вести, 400 было арестовано ${ }^{204}$.

22 января состоялась похоронная процессия в память о погибших во время событий в Баку. В ней приняли участие свыше 1 млн. человек. На территории, прилегающей к площади Азадлыг, и на стенах перед зданием ЦК, появились надписи: «Тбилиси, Баку. Какой город будет расстрелян следующим?», “Горбачёв, ты палач, ты лжец, ты враг перестройки", «Палач Язов, вон из Азербайджана». Похоронная процессия сопровождалась массовым сожжением партийных билетов.

Вокруг событий в Баку была образована жёсткая информационная блокада. Более месяца после событий не работала республиканское телевидение. Не издавались местные газеты. Распространяемые в те дни в Азербайджане номера центральных газет «Правда», «Известия», «Красная звезда» и другие издания центральной печати отличались от номеров, распространявшихся в Москве и в других городах СССР. Материалы номеров центральной печати, направленные против республики, широкие кампании в связи с военной операцией по «всенародной защите» Баку, не включались в номера этих же изданий, печатавшихся в Баку. Газета «Правда», являвшаяся идеологическим рупором Советской империи, 22 января писала: «Заявления о якобы гибели женщин и детей в результате мер, принятых для введения чрезвычайного положения, носят открыто провокационный характер. Следует ещё раз повторить: это преднамеренная ложь! Их цель - поднять население против Советской Армии и правоохранительных органов» ${ }^{205}$. В советской печати такие расхождения были отмечены впервые.

Первым в прорыве информационной блокады вокруг событий в Баку стало выступление в Постоянном представительстве Азербайджана в Москве 21 января 1990

\footnotetext{
${ }^{203}$ Лебедь А.И. За державу обидно... Москва, 1995, с.289-290

${ }^{204}$ Балаев А., Мирза Р. Там же, с.190-191

${ }^{205}$ Газета «Правда, 22.01.1990.
} 
года бывшего члена Политбюро ЦК КПСС Гейдара Алиева, который подверг критике лиц, совершивших этот инцидент, заявив, что считает этот акт противозаконным. В своем выступлении Г.Алиев раскрыл ошибки, допущенные кремлевским и республиканским руководством в Карабахском вопросе, который стал основной причиной трагических событий в Баку. Фактически это выступление Г.Алиева положило начало его возращению в большую политику после отставки в 1987 году.

Ровно через год после Баку эти события, но в меньшем масштабе, повторились в Вильнюсе. Однако ни события апреля 1989 г. в Тбилиси, с числом жертв 18 человек, ни события января 1991 г. в Вильнюсе, с числом жертв 13 человек, не идут ни в какое сравнение с событиями в Баку. Дело не в числе жертв, а в масштабах и формах проведения операции.

С этой точки зрения события в Баку 20 января 1990 г. по масштабу и стратегической направленности сопоставимы с военными операциями советской армии в Венгрии 1956 г. и Чехословакии 1968 г. Победа Советской армии при захвате города оказалась «пирровой победой». После военной операции в Баку коммунистический режим в республике потерпел полный крах и Азербайджан твердо встал на путь восстановления своей независимости.

\section{Streszczenie:}

W oparciu o dowody bezpośrednich uczestników wydarzeń, artykuł rozważa przyczyny tragicznych wydarzeń z 20 stycznia 1990 r. W Baku. Autor dochodzi do wniosku, że głównymi przyczynami tragicznych wydarzeń z 1990 r. Był ruch separatystyczny w Górskim Karabachu, aby przyłączyć się do tego terytorium do armeńskiej SRR, a także starania przywódców radzieckich o stłumienie narodowego ruchu Azerbejdżanu w celu ochrony integralności terytorialnej republiki. Pod względem skali i formy operacja armii radzieckiej w Baku 20 stycznia 1990 r. Była porównywalna z operacjami wojskowymi na Węgrzech w 1956 r. I Czechosłowacji w 1968 r. Zwycięstwo armii radzieckiej podczas zdobycia miasta okazało się „Pyrrhic”. Po operacji wojskowej w Baku, upadku ZSRR Po operacji wojskowej w Baku reżim komunistyczny w republice całkowicie się rozbił, a Azerbejdżan zdecydowanie stanął w obronie niepodległości.

\section{Słowa kluczowe:}

Azerbejdżan, Armia Radziecka, Baku, Republika, Górski Karabach

\section{Key words:}

Azerbaijan, Soviet Army, Baku, Republic, Nagorno-Karabakh 


\section{Bibliografia:}

1. М.С. Горбачев, Жизнь и реформы [Life and Reforms]. Книга 1, Москва, 1995, c.506.

2. Ф. Бобков, КГБ и власть [KGB and Power]. Москва, 2009, с. 298-299.

3. В. Гусейнов, Больше, чем одна жизнь [More than One Life]. Книга 2. Москва, 2013, с.118-119.

4. В Политбюро ЦК КПСС. По записям Анатолия Черняева, Вадима Медведева, Георгия Шахназарова (1985-1991). Сост. А. Черняев (рук. проекта), А. Вебер, В. Медведев. Москва, 2008, с.571.

5. А.Балаев, Р.Мирза, События 20 января. Документы, позиции, комментарии (1990-2000) [20 January Events. The Documents, Views, Comments (1990-2000)]. Баку, 2000, с.45-55.

6. А.Грачев, Горбачёв. Человек, который хотел, как лучше...[Gorbachev. The Man who wanted to do what is for the better]. Москва, 2001,c.136

7. А.И. Лебедь, За державу обидно... [It hurts for the state]. Москва, 1995, с.289-290.

8. Газета «Правда», 22.01.1990 